\title{
Use of collection material of pease and chick pea for searching sources according to economic valuable tags and creation of collections of these crops
}

\author{
N. Krynychna, \\ Candidate of Biological Sciences \\ V. Hromiak, \\ candidate of agricultural sciences \\ National Scientific Center «Institute of Soil Science and Agrochemistry named after O.N. \\ Sokolovsky»
}

The purpose. To select specimens of pease and chick pea according to economic valuable tags on the basis of basic collections of cultivars of starting material as sources of tags for selection. Methods. Specimens of pease and chick pea were sowed in the collection seed bed with a gathering ground of plants $30 \times 10 \mathrm{~cm}$. Through each 10 specimens they sowed cultivarsstandards. Phenological observations beginning from shoots up to complete ripeness of plants were carried out on the interphase periods; they fixed morphological characters of plants. Results. For 5 years of probes on the basis of basic collections 158 valuable specimens of pease and chick pea are allocated. All these specimens are systematized according to productivity, elements of crop structure, duration of vegetation period, morphological features and resistance to disease and pests. Conclusions. Attribute collections of pease and chick pea (a diverse starting material for selection of new generations of cultivars accommodated for modern production conditions) are created. Bibliogr.: 10 titles.

Key words: pease, chick pea, selection, cultivar, source of tags, gene pool of crop.

Breeding and seed production of field crops in Ukraine, along with growing technologies are the basis for their sustainable production, improving the competitiveness of country in the global market. Therefore, the resolution of the National Academy of Agrarian Sciences of Ukraine, adopted on the basis of field meeting of July 17, 2015 in Kharkiv on "Scientific and organizational principles of plant breeding and seed production of field crops in Ukraine» to the institutions that perform functions of the main institutions coordination of research on breeding and seed tasked to create new competitive breeding development, using the best genetic plasma and labourer collections of the institute-collaborators of the programs. Scientific institute-originators of varieties and hybrids of field crops were instructed to use actively the gene pool of the National Center of plant genetic resources of Ukraine in breeding work, expand the genetic diversity of working collections, and to create and evaluate new original material to apply modern molecular genetic and biotechnological methods, introduce marker selection. Effective work on development of new plant varieties and hybrids of crops without a focused analysis of the source material is impossible [5].

Purpose - parsel out of samples of peas and chickpeas for agronomic characteristics based on the basic collections, creating collections of original material varieties as sources of signs for breeding. Materials and methods of research. In the National scientific center «Institute for soil science and agrochemistry research named after O.N. Sokolovskiy» in close cooperation with the main institution - the National centre for plant genetic resources of Ukraine (Plant production institute named. after. V.Ya. Yuryev), for five years carried out work on creation of of peas and chickpeas collections with valuable agronomic signs. The objects of research were collectible designs of peas and chickpeas. Our basic collection (representing basic gene pool of culture and formed from samples that cover the full range of variability of signs within the culture) comprise 1117 samples peas and 831 samples chickpeas. There are samples from Ukraine, Canada, USA, Bulgaria, Poland, Germany, Austria, Syria, Afghanistan, Iran, Finland, Great Britain, Romania, France, Japan and so on. The work with them carried out in accordance with the «Guide to learn collections of legumes» [6]. Description of samples for morphological features and biological properties were carried out according to the respective 
families of classifiers: Pisum L. [10], Cicer L. [3,9]. The data were treated with conventional methods of mathematical statistics in the collections legumes study [1].

Samples of peas and chickpeas sowed in the collection nursery (50 seeds per section 1 ) with the nutrition area about $30 \times 10 \mathrm{~cm}$. Every 10 samplers were sew sampler-standarts.

The study of the economic and biological signs, botanical traits and breeding values of each of the studied samples was carried out through their reproduction in different years (minimum three years). During the growing season phenological observations from germination to full maturity of the plants were carried out on interphase periods fixed morphological features of plants. In vitro plants were analyzed for yield structure elements.

Results and discussion. After five years of research (years 2011-2015) on the base the basic collections 158 samples of peas and chickpeas were allocated. All these samples for yield, yield structure, elements of harvest structure, length of the growing season, plants morphological characteristics and resistance to diseases and pests were systematized. Results of the work for economy value signs of pea selecting are represented in the table 1.

Table 1. Pea samples, what were picked out for some value signs or their compositions development

\begin{tabular}{|c|c|c|c|}
\hline № & Signs & $\begin{array}{l}\text { Samples } \\
\text { quantity }\end{array}$ & $\begin{array}{l}\text { Samples } \\
\text { (signs origins) }\end{array}$ \\
\hline \multirow[t]{4}{*}{1} & $\begin{array}{l}\text { Vegetation period, days: } \\
\text { - ultra-early ripe (to } 55 \text { days) }\end{array}$ & 2 & $\begin{array}{l}\text { Fardivil,UD0100879, } \\
\text { LDS01134,NLD }\end{array}$ \\
\hline & - early ripe (56-60 days) & 41 & $\begin{array}{l}\text { Taking sight on, UD0101943, } \\
\text { RUS; Me Zean`s Little, UD0102067, } \\
\text { BGR; Alderman, UD0101936, USA etc. }\end{array}$ \\
\hline & - medium early ripe (61-70) & 52 & $\begin{array}{l}\text { Vada, LDS01132, NLD; Behind } \\
\text { Ural } 3 \text { UD0102464, RUS; Jmega, } \\
\text { UD0102473, NLD and others }\end{array}$ \\
\hline & - medium ripe (71-75) & 1 & Present. UDS01135, RUS \\
\hline \multirow[t]{2}{*}{2} & $\begin{array}{l}\text { Plants height, cm: } \\
\text { - short stem (31-60) }\end{array}$ & 84 & $\begin{array}{l}\text { Fardivil UD0100879, FRA; } \\
\text { Mascot (PBTC), UD0100965, BGR and } \\
\text { others }\end{array}$ \\
\hline & - medium height (61-100) & 12 & $\begin{array}{l}\text { Blaugrune englische, UD0101086; } \\
\text { Alderman, UD0101936, USA; Magnate, } \\
\text { UD0102446, UKR and others }\end{array}$ \\
\hline 3 & Many flowers & 1 & $\begin{array}{l}\text { Meadow } 363 / 08 \\
\text { UD0102446,UKR and others }\end{array}$ \\
\hline 4 & $\begin{array}{l}\text { Great seeds(mass of } 1000 \text { seeds } \\
(>250 \text { gramms) }\end{array}$ & 2 & Taking sight on UD0101943, RUS \\
\hline 5 & $\begin{array}{l}\text { High fastened of beans } \\
\text { (more then } 45 \mathrm{~cm} \text { above the land) }\end{array}$ & 19 & $\begin{array}{l}\text { Meadow } \quad 363 / 07, \\
\text { UD0102497, UKR; Meadow } \\
\text { 180/08, UD0102499, UKR; } \\
\text { 1812-5, LDS01127 and others }\end{array}$ \\
\hline \multirow[t]{2}{*}{6} & $\begin{array}{l}\text { Seeds harvest (\% to the } \\
\text { standard): } \\
\text { - medium (96-115) }\end{array}$ & 8 & $\begin{array}{l}\text { Meadow 177/08, LDS01051, UKR; } \\
\text { Magnate, UD0102446, UKR and others }\end{array}$ \\
\hline & high 115 & 8 & $\begin{array}{l}\text { Meadow 89/06, UD0102495, } \\
\text { UKR; Meadow } \quad 363 / 07, \\
\text { UD0102497, UKR and others }\end{array}$ \\
\hline 7 & For the signs complex & 5 & $\begin{array}{l}\text { Meadow 363/08, LDS01070, } \\
\text { UKR; Taking sight on, UD0101943, } \\
\text { RUS and others }\end{array}$ \\
\hline
\end{tabular}


For the duration of peas growing season, largest number of samples in the collection presented precocious and medium - ripening varieties. When targeting ultraforward breeding and middle-grades, the shortage of source material will be felt. Similarly, there are not culture samples with very short stalk $(60 \mathrm{~cm})$ and tall $(100 \mathrm{~cm})$. There are only a few plants allocated with multiflowers and big seeds signs. However, the number of samples with high attachment of the lower tier of beans and a sufficient level of productivity, in our opinion, fully satisfy the demands of breeders.

Results of the work for allocation of value signs of chickpea are represented in the table 2.

In difference from pea, selectionists, who plan to do the chick-pea selection there is enough starting material for their work in all directions for economy value signs. Samples with big harvesting, different for duration vegetation period, plants height are broadly represented

The final, very important stage of work after studying specimens is to create collections. Collections gene pool of plants - a set of samples that differ by genotype. It is focused reserve samples of plants for use in agriculture (primarily as source material for breeding), scientific, environmental, educational and other programs, and requires the preservation of a viable state and the genetic integrity [7]. In 2013 the National center of plant genetic resources of Ukraine we have registered feature collection chickpeas for the Steppe zone of Ukraine, which consists of 132 samples chickpeas from 26 countries (Ukraine, Iran, Mexico, Spain, etc.) (certificate number 00169) ( Figure 1). It should be noted that foreign examples are often characterized by differences in genetic determination of characteristics that are the basis for the formation of transgressive forms, when used as parental forms in hybridization with domestic [4].

Table 2. Chickpea samples, what are picked out for the level of some value signs or their compositions

\begin{tabular}{|c|c|c|c|}
\hline № & Signs & $\begin{array}{l}\text { Samples } \\
\text { quantity }\end{array}$ & Samples (signs origins) \\
\hline \multirow[t]{3}{*}{1} & $\begin{array}{l}\text { Duration of vegetation period days: } \\
\text { - very ultra-early ( }<70 \text { days) }\end{array}$ & 26 & $\begin{array}{l}\text { Flip 04-35 c, UD0501869, SYR; Flip } \\
\text { 03-112 c, UD0501875, SYR; Flip 02- } \\
\text { 04c, UD0501878, SYR }\end{array}$ \\
\hline & $\begin{array}{l}\text { - ultra-early ripe } \\
\text { (71-75 days) }\end{array}$ & 34 & $\begin{array}{l}\text { Panskiy, LDS00763, UKR; 41859, } \\
\text { LDS00769, CAN and others }\end{array}$ \\
\hline & - early ripe (76-80) & 2 & $\begin{array}{l}\text { Meadow 114/07, LDS00752, UKR; } \\
\text { Meadow 131/08, LDS00755, UKR }\end{array}$ \\
\hline \multirow[t]{2}{*}{2} & $\begin{array}{l}\text { Seed size } \\
\text { (mass of } 1000 \text { seeds }) \\
\text { - big }(251-350 \mathrm{~g})\end{array}$ & 15 & $\begin{array}{l}413 \text { 2, LDS00767, CAN; } 41859 \text {, } \\
\text { LDS00768, CAN; } 428 \text { 1, LDS00769, CAN and } \\
\text { others }\end{array}$ \\
\hline & - very big (>350 g) & 18 & $\begin{array}{l}328 \text { S 8, LDS00772, CAN; } 493 \text { 24, } \\
\text { LDS00776, CAN; X2001th75-4, LDS00743 and } \\
\text { others }\end{array}$ \\
\hline \multirow[t]{3}{*}{3} & $\begin{array}{l}\text { Length of stem } \\
\text { - short }(20-35 \mathrm{~cm})\end{array}$ & 8 & $\begin{array}{l}336 \text { 2, LDS00766, CAN; X2001th75-4, } \\
\text { LDS00776, CAN; X2001th76-15, LDS00744, } \\
\text { CAN and others }\end{array}$ \\
\hline & - medium $(35-45 \mathrm{~cm})$ & 30 & $\begin{array}{l}\text { Flip 06-139c, UD0501947, SYR; Flip } \\
\text { 05-145c,UD0501949,SYR and others }\end{array}$ \\
\hline & -long $(46-60 \mathrm{~cm})$ & 24 & $\begin{array}{l}439 \text { as } 22 \text { LDS00770, CAN; } 463 \text { 2, LDS00771, } \\
\text { CAN; } 438 \text { 29, LDS00775, CAN and others }\end{array}$ \\
\hline 4 & $\begin{array}{l}\text { Conformity to mechanical } \\
\text { harvest (fastening of beans above the } \\
\text { land) }\end{array}$ & 7 & $\begin{array}{l}\text { Flip 04-35c, UD0501869, SYR; Flip 02- } \\
\text { O4c,UD0501878, SYR; Flip 02-89c, UDO0501881, } \\
\text { SYR; Flip 03-57c, UD0501899, SYR }\end{array}$ \\
\hline 5 & $\begin{array}{l}\text { High harvest of seed (more } \\
\text { then } 15 \% \text { above the standard) }\end{array}$ & 26 & $\begin{array}{l}\text { Flip 03-112c, UD0501875, SYR; Flip } \\
\text { O3-57c, UD0501899, SYR; Flip 06-106, } \\
\text { UD0501931, SYR; }\end{array}$ \\
\hline 6 & For signs complex & 8 & $\begin{array}{l}\text { Flip 02-04c, UD0501878, SYR; Meadow 51/09, } \\
\text { LDS00739, UKR and others }\end{array}$ \\
\hline
\end{tabular}




\begin{tabular}{|c|c|c|c|c|c|c|c|c|c|c|c|c|c|c|}
\hline REG_LDS & NAME_SAMP & $D^{1} 0$ & $\mathbf{v}$ & F5 & M1 & M2 & M4 & P2 & & P1 & P3 & $P \propto$ & $\overline{Y f}$ & $\mathrm{Ya}$ \\
\hline LDS00188 & Local & IRN & 3 & 80,1 & 29,8 & 17,3 & 1,0 & 253,5 & 5 & 9,6 & 319,7 & 3 & & \\
\hline LDS00125 & Gram type 13 & IND & 3 & 78,6 & 33,8 & 19,0 & 1,3 & 163,8 & 6 & 13,0 & 432,9 & 3 & & \\
\hline LDS00244 & Xaxyt & UKR & 7 & 73,7 & 32,6 & 21,1 & 1,2 & 446,6 & 2 & 11,5 & 382,9 & 3 & & \\
\hline LDS00356 & Pink & UZB & 3 & 64,3 & 19,6 & 10,5 & 1,2 & 162,9 & 3 & 8,7 & 289,7 & 4 & & \\
\hline LDS00189 & - & IRN & 3 & 76,9 & 24,4 & 11,7 & 1,5 & 167,4 & 9 & 9,4 & 313,0 & 2 & & \\
\hline LDS00078 & Chickpea & BGR & 7 & 77,9 & 35,9 & 20,8 & 1,2 & 242,4 & 2 & 10,6 & 353,0 & 4 & & 7 \\
\hline LDS00235 & Hybrid 25 & RUS & 7 & 77,9 & 39,2 & 26,4 & 0,9 & 330,4 & 3 & 26,3 & 875,8 & 4 & 5 & 7 \\
\hline LDS00048 & Local & AFG & 3 & 79,4 & 34,4 & 18,6 & 1,5 & 179,9 & 8 & 10,1 & 336,3 & 2 & 7 & \\
\hline LDS00049 & - & AFG & 7 & 77,9 & 26,1 & 15,8 & 1,3 & 122,2 & 2 & 2,6 & 86,6 & 3 & & \\
\hline
\end{tabular}

Figure 1. Part of a collection of chickpea (created in 2013)

In 2014 was created the collection of pea (Figure 2). Collection peas, chickpeas and a collection like, formed by classifier signs respective taxa using standard samples. Collection of pea for the Steppe zone of Ukraine includes 132 sample of 13 countries from which they originate.

\begin{tabular}{|l|l|l|l|l|l|l|l|l|l|l|l|l|l|}
\hline REG_LDS & $\begin{array}{l}\text { NAME_SA COU_- } \\
\text { MP }\end{array}$ & ORIG & F5 & M1 & M2 & N1 & N2 & P1 & P2 & B & ZNO & Q \\
\hline LDS01107 & $985-23$ & CAN & 1 & 61 & 40,6 & 31,9 & 7,3 & 24,2 & 3,9 & 3,2 & 152,5 & 2 & 5 \\
\hline LDS01108 & $1312-14$ & CAN & 1 & 61 & 41,7 & 27,8 & 9,9 & 38,1 & 4,9 & 3,8 & 127,8 & 5 & 5 \\
LDS01109 & $1330-7$ & CAN & 1 & 62 & 46,4 & 38,3 & 6,8 & 24,5 & 7,0 & 3,6 & 175,2 & 2 & 5 \\
LDS01110 & $1370-5$ & CAN & 1 & 62 & 53,0 & 39,5 & 6,7 & 27,7 & 5,0 & 4,1 & 179,5 & 5 & 5 \\
LDS01111 & $1400-8$ & CAN & 1 & 65 & 43,6 & 34,9 & 9,1 & 37,4 & 5,4 & 4,3 & 143,5 & 2 & 5 \\
LDS01112 & $1408-6$ & CAN & 1 & 60 & 41,2 & 33,2 & 7,7 & 29,0 & 4,6 & 3,7 & 164,8 & 2 & 5 \\
LDS01113 & $1410-15$ & CAN & 1 & 62 & 57,8 & 43,3 & 9,7 & 34,3 & 5,7 & 3,6 & 172,2 & 2 & 5 \\
\hline
\end{tabular}

Figure 2. Part of a collection of pea (created in 2014)

Signs, which created collections: the origin of the samples direction of the (V), group maturity (F5), the length of the stem (M1), height of attachment of lower beans (M2), the mass of seeds from one plant (P1), color seed coat (ZNO ) crumbling / not crumbling (for pea) (Q) and others.

\section{Conclusions.}

1. Signs collections samples of peas and chickpeas - diverse source material for breeding new generations of varieties, adapted to modern conditions of production were formed.

2. Using data from the National Centre for Plant Genetic Resources of Ukraine enables for breeders to reduce time to search parental forms.

3. Collection could be used both in profile scietific institutions, experimental stations and in educational programs of agrarian university on selection courses.

\section{Bibliography}

1. Dospekhov B. A. Metodyka polevoho opыta/B. A. Dospekhov. - M. : Kolos, 1979. - 416 s.

2. Identyfikatsiya oznak zernobobovykh kul'tur (kvasolya, nut, sochevytsya): navchal'nyy posibnyk/V.V. Kyrychenko, L.N. Kobyzyeva, V.P. Petrenkova [ta in.]. - Kharkiv: VAT «Vydavnytstvo «Kharkiv», 2009. - 117s.

3. Klassyfykator roda Cicer L. - L., 1975. - 13 s.

4. Kobyzyeva L.N. Zbahachennya Natsional'noho henbanku roslyn Ukrayiny zrazkamy henofondu zernobobovykh kul'tur vitchyznyanoho ta zarubizhnoho pokhodzhennya/L.N. Kobyzyeva, O.M. Bezuhla, R.L. Bohuslavs'kyy //Henetychni resursy roslyn. - Kharkiv, 2010. - s. 9-19.

5. Kobyzyeva L.N., Bezuhla O.M., Pot'omkina L.M., Dmitriu T.O. Formuvannya oznakovykh kolektsiy zernobobovykh kul'tur (horokh, nut, sochevytsya) v NTS·HRRU». I/Zbirnyk naukovykh prats' Luhans'koho natsional'noho ahrarnoho universytetu \#20/32. - Luhans'k, 2002. - S. 25-31. 
6. Metodycheskye ukazanyya po yzuchenyyu kollektsyy zernovыkh bobovыkh kul'tur. - L. : VYR, 1975. $59 \mathrm{~s}$.

7. Ryabchun V. K. Natsional'nyy tsentr henetychnykh resursiv roslyn Ukrayiny/V. K. Ryabchun, N. V. Kuz'myshyna, L. N. Kobyzyeva, K. I. Dokukina, R. L. Bohuslavs'kyy. - Kharkiv, 2012. - 28 s.

8. Skyt-s'kyy V.Yu. Analiz kolektsiyi nutu dlya vykorystannya $v$ selektsiyi na pidvyshchennya tekhnolohichnosti pry vyroshchuvanni/ V.Yu. Skyt·s'kyy//Henetychni resursy roslyn. - Kharkiv, 2010. - s. 40-45.

9. Shyrokyy unifikovanyy klasyfikator rodu Cicer L. - Kharkiv, 2012. - 45 s.

10.Shyrokyy unyfytsyrovannыy klassyfykator SЭV y mezhdunarodnыy klassyfykator SЭV roda Pisum L. L., 1981. $-46 \mathrm{~s}$. 